\title{
The Role of Religion in the Connection between Estonian Settlements in Abkhazia and the Estonian Homeland
}

\author{
Aivar Jürgenson \\ Tallinn University, School of Humanities, Centre of History, \\ Archaeology and Art History, Uus-Sadama 5, IoIzo Tallinn, \\ aivarj@tlu.ee
}

\begin{abstract}
The Estonian settlements in Abkhazia developed in the 1880s, and soon after were taken under the wing of the Russian Lutheran Church. Since most of the Lutheran pastors in tsarist Russia had been educated at the University of Tartu, and many of them came from the Baltic provinces, they often also spoke Estonian. The article examines the relations of the settlers with the pastors, some of whom had previously served in Estonia. It also looks at the role played by the parish clerk/schoolteachers of the settlements who came from Estonia or other Estonian settlements in tsarist Russia.
\end{abstract}

Keywords: diaspora; Caucasus; Abkhazia; Estonian settlements; religion; Lutheran church; tsarist Russia

\section{INTRODUCTION}

In the I88os, several Estonian villages were established in Abkhazia, i.e. Estonia, Ülem-Linda and Alam-Linda in Sukhum district of Kutais Governorate, and Salme and Sulevi in the Black Sea district of Kuban Governorate (as of 1896, the Sochi district of the Black Sea 
Governorate). The arrival of Estonian settlers was part of the implementation of tsarist colonial policy in Abkhazia. After the tsarist authorities liquidated the principality of Abkhazia in I864 and expelled most of the Abkhazians, colonists from other parts of the country, as well as from abroad (for example Christian Armenians and Greeks from the Ottoman Empire) were settled in the emptied areas. For the remaining Abkhazians, specific areas were identified were they could and could not live. The Abkhazians were also banned from territories where Estonian settlements developed, and therefore there was minimal contact between the Estonians and the Abkhazians. Only the inhabitants of the village of Estonia, which was built on the shore of the Kodor River, had contact with the Abkhazians living on the other side of the river. The Kodor River marked the border north of which the Abkhazians could not settle. The tsarist government, being allergic to the local Muslims after the protracted war in the Caucasus, prohibited them from marrying Christians, giving Muslim names to children, and burying their dead according to Muslim traditions. They also banned the activities of the mullahs and closed

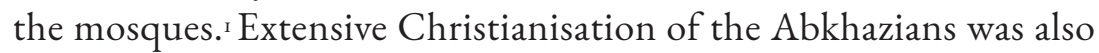
organised to "calm" the area. ${ }^{2}$ Generally, new Christian settlers became the Estonians' neighbours. Bulgarians, Moldovans, Mingrelians and Armenians were among those in the vicinity of Estonia village, Greeks, Germans and Mingrelians near Alam- and Ülem-Linda, while Armenians and Moldovans settled near Salme and Sulevi. Although there were a few hundred Orthodox among the Estonian settlers, the majority belonged to the Lutheran Church. It is known that the Orthodox Estonians did not have a lively church life, mainly due to their poor knowledge of Russian. Their children attended the same schools as the other Estonians, but did not attend the Lutheran religious education classes. There was a wish to have a priest who understood Estonian in the Sukhum Orthodox Church, but nothing ever came of it. ${ }^{3}$

Samuel Sommer, an Estonian settlement activist who travelled through the Estonian settlements of the Russian empire before and during World War I, and therefore had a good overview of their lives, has emphasised the role of Lutheranism in preserving the ethnic identity

I Цакветадзе, Г. Конфессиональные аспекты этнической куьтуры народов современной Абхазии. КчГУ-ИНОА, Карачаевск, Сухум, 2009, 89.

2 Квициния М. Б. Религиозность как фактор влияния на политические процессы (на материале политической истории Абхазии XIX века). - Абхазоведение, 2012, 8, I82-I88.

3 Elanik. Suhumist. - Uus Aeg, I9OI, II6, 3; see also Meomuttel, J. Eesti asunikud laialises Vene riigis. Esimene katse sônumid kôikide Eesti asunduste üle tuua. Postimehe trükikoha kirjastus, Jurjev, 1900, 44. 
of the Estonian settlers. He provided examples of Orthodox Estonian villages that quickly became Russified and contrasted them with the Lutheran Estonian villages, which, despite their long history, retained their Estonian character. As one of the reasons, he saw the Russians' greater openness to Orthodoxy as paving the way for the faster assimilation of Estonians. ${ }^{4}$

This article examines the religious life of Estonians in Abkhazia, but also the settlements' connections with their Estonian homeland, which were especially pronounced through the church. Most of the clergy and parish clerk/schoolteachers who came to serve the settlers came from Estonia, bringing with them news about developments in the homeland, and in addition to education also promoting cultural life and maintaining ties both with Estonia and between Estonian settlements. In this way their contribution to maintaining links between the settlements and the homeland cannot be underestimated. The transnational perspective in migration research emphasises that migration might not be a single act, but could involve repeated relocations as well as lasting cross-border relationships between the migrants and those left behind. ${ }^{5}$ Below we will see that the rotation of both pastors, and especially the parish clerk/schoolteachers, between the homeland and the settlements was frequent, which ensured that cultural developments reached settlements quickly. Although this is not the subject of this article, it is also worth noting that the movement of the settlers themselves between the homeland and the settlements was also more frequent than is usually thought.

\section{DIASPORA AND RELIGION}

The role of religion in the formation and development of diaspora communities, as well as their connection with the homeland has been addressed in both historical and anthropological terms and in many cultural contexts. Just as, a hundred years ago, Samuel Sommer noted the role of Lutheranism in preserving Estonian ethnicity, the importance of religion for diaspora identity has been dealt with often in twentieth and twenty-first century diaspora studies. The Jewish diaspora, which has always primarily considered itself a religious community, is often

4 Sommer, S. Väljarändamise ja eesti asundused endise Venemaa piirides. Rahvusarhiiv, Eesti Riigiarhiiv (RA, ERA), 4402.I.38, I4.

5 Faist, T.; Fauser, M.; Reisenauer, E. Transnational Migration. Polity Press, Cambridge, $2 \mathrm{OI} 3$, I. 
presented as the prototype. The concept of the diaspora came into circulation through the Greek translation of the Bible indicating the scattering among foreign nations that served as punishment for a nation that deviated from the right path. The metaphor of Babylonian captivity, essentially forced exile, has always symbolised misery, isolation, insecurity and trauma, ${ }^{6}$ but originally its message related to disobedience to God and its consequences. However, based on the Jewish example, the so-called victim diaspora has also been mentioned in twentieth century diaspora research and, in addition to the Jews, the Armenian and Greek diasporas have often been mentioned. Just like the Jewish diaspora, the Armenian and Greek diasporas emphasise the role of religion, along with the victim tradition, in their identity, ${ }^{7}$ although at the same time they are ethnic diasporas. Of course, there are also diaspora communities, such as the Huguenots or Hutterites, Mennonites or Amish, that have clearly emerged on religious grounds, and the Tibetan Buddhists have also sometimes been called a religious diaspora ${ }^{8}$ although even in these cases the ethnic and religious component coexist.

The connection between the ethnic and religious elements seems to be characteristic of diaspora identity more generally. Gary D. Bouma has argued that it is important for the immigrants from various backgrounds who come to Australia to build churches, synagogues, mosques, temples and pagodas, even though almost none of them have come to Australia for religious reasons. ${ }^{9}$ In the case of Asian migrants in the United Kingdom, Kim Knott shows how religion has become the core of identification for people whose original reason for migrating was primarily economic, educational or social. ${ }^{10}$ Based on the last two examples, Martin Baumann explains the phenomenon as follows: living abroad and the fear of possible loss rekindles people's interest in the religious beliefs, practices and values of their homeland. Especially when migrants perceive discrimination, religion, as a conceptual and emotional resource begins to strengthen the group's sense of solidarity. ${ }^{11}$ Religiosity strengthens ethnicity and vice versa. In a foreign cultural environment,

6 Cohen, R. Diasporas and the Nation-State: From Victims to Challengers. - International Affairs, 1996, 72, 3, 507-508.

7 Kokot, W., Tölölyan, K., Alfonso, C. Introduction. - Diaspora, Identity and Religion. New Directions in Theory and Research. Ed. by W. Kokot, K. Tölölyan, C. Alfonso. Routledge, London, New York, 2004, 2-3, 6.

8 Safran, W. Deconstructing and Comparing Diasporas. - Diaspora, Identity and Religion, I2.

9 Bouma, G. D. Many Religions, All Australian: Religious Settlement, Identity and Cultural Diversity. Christian Research Association, Kew, 1996, $53-57$.

Io Knott, K. The Religions of South Asian Communities in Britain. - A New Handbook of Living Religions. Ed. by J. Hinnells. Blackwell, Oxford, 756.

II Baumann, M. A Diachronic View of Diaspora, the Significance of Religion and Hindu Trinidadians. - Diaspora, Identity and Religion, I7I-I73. 
ethnic and religious diasporas can merge in the eyes of members, even at the terminological level. For example, Estonian settlers in Siberia have called their Lutheran religion the Estonian religion (eesti usk), i.e. the Lutheran upbringing, which originated from the homeland. The importance of the sacraments and religion in Estonian diaspora identity was a factor that influenced the religious life of the settlements and kept settlers focused on the homeland. ${ }^{12}$

Yossi Shain and Aharon Barth define diaspora as a community of people of common origin living outside their ethnic or religious homeland. ${ }^{13}$ Links with homeland or country of origin have been emphasized quite unanimously in various diaspora typologies and taxonomies. ${ }^{14}$ W. Safran goes even further and considers the relationship with the homeland to be critical to the definition: members of the diaspora retain a memory of their homeland, cultural ties with the homeland and a symbolic or practical orientation to the homeland. In this respect, members of a diaspora differ from other immigrant communities, ${ }^{15}$ something which, based on Safran's presentation of his methodical position on the importance of ties with the homeland as part of the identity of the diaspora, has become widely accepted. ${ }^{16}$

The role of land of origin in the identity of the diaspora is certainly decisive in nature: members of the diaspora identify themselves by land of origin, even if they do not always sympathise with developments there. Consider, for example, the Bolshevik-minded Estonians who lived in the Soviet Union in the I920s and I930s. If you read the Estonian Bolshevik newspapers that appeared in Leningrad ${ }^{17}$ and Novosibirsk ${ }^{18}$, there is no doubt that these authors harboured hostile attitudes towards the independent Republic of Estonia. In most cases, however, diaspora communities have a desire to identify with their land of origin (even if they despise its political regime), which provides them with cultural and often economic resources. In many cases, lively communication takes place between the country of origin and the diaspora. However,

I2 Jürgenson, A. Siberiga seotud. Eestlased teisel pool Uuraleid. Argo, Tallinn, 2006, 269.

I3 Shain, Y., Barth, A. Diasporas and International Relations Theory. - International Organization, 2003, 57, 3, 45I.

I4 Safran, W. Diasporas in Modern Societies: Myths of Homeland and Return. - Diaspora. A Journal of Transnational Studies, I99I, I, I, 83-84; Cohen, R. Diasporas and the Nation-State, 516; Kokot, W. Diaspora. Ethnologische Forschungsansätze. - Interkulturelle Kommunikation in der Diaspora: die kulturelle Gestaltung von Lebens- und Arbeitswelten in der Diaspora. Hrsg. von A. Moosmüller. Waxmann, Münster, 2002, 32-34.

Is Safran, W. Deconstructing and Comparing Diasporas. - Diaspora, Identity and Religion, Io, 16.

I6 Wofford, T. Whose Diaspora? - Art Journal, 2016, 75, I, 75.

17 The newspaper "Edasi", published in Petrograd/Leningrad in 1917-1937.

I8 The newspaper "Siberi Teataja" in Novonikolajevsk/Novosibirsk in 1922-1930. 
we should keep in mind that the diaspora does not function as an impersonal collective organism. The diaspora consists of members, some of whom are more active than others. Yossi Shain and Aharon Barth divide members of the diaspora into three categories: core members, passive members, and silent members. It is the members of the first category who are the elite that organises the diaspora, directs its activities and mobilises other members, i.e. the passive members, who can be mobilised when led by active leaders. The authors define the majority of the diaspora as those who do not participate in diaspora activities, but who can be mobilised in times of crisis as silent members. ${ }^{19}$ The cultural elite of the diaspora also plays a crucial role in developing ties with the homeland. When speaking about the Estonian diaspora in the East, ${ }^{20}$ including in the Caucasus, the cultural elites were in many cases the parish clerk/ schoolteachers of the settlements. As noted above, their activities often extended beyond the administration of ecclesiastical sacraments and the provision of schooling, although the framework for these relationships was provided by the church.

\section{ORGANISATION OF THE LUTHERAN CHURCH IN TSARIST RUSSIA}

Although Lutheran congregations were active in Russia in the sixteenth and seventeenth centuries, the situation changed significantly when, as a result of the Great Northern War, the Swedish Baltic provinces became part of the tsarist state. The inhabitants of these states, Lutheran Estonians, Latvians and Baltic Germans, supplemented the relatively sparse ranks of Lutherans in the Russian Empire. The church was further supplemented at the end of the eighteenth century when the manifesto (22 June 1763) of Catherine the Great, who was of German origin, invited foreigners to settle in the territories of the tsarist state, i.e. on the shores of the Volga River and the Black Sea, as well as in the Caucasus. The colonists were offered freedom of religion, the right to self-government, and tax exemptions. The main colonisation came from Prussia, where the economic situation was difficult after the Seven Years' War (1756-1763). However, there were also colonists from other

I9 Shain, Y., Barth, A. Diasporas and International Relations Theory. - International Organization, 2003, 57, 3, 451.

20 See Tammaru, T., Kumer-Haukanômm, K., Anniste, K. Eesti diasporaa kujunemise kolm lainet. - Eestlased ja eesti keel välismaal. Koost K. Praakli, J. Viikberg. Eesti Keele Sihtasutus, Tallinn, 20I0, 35 . 
German states. There were many Lutherans, including Pietists, among the newcomers. ${ }^{21}$ During the reign of Catherine the Great, Lutherans from the Estonian territories also arrived in the newly colonised lands when a settlement of Swedes from Hiiumaa was founded on the right bank of the Dnieper, on the border of the Crimean Khanate, which still existed at the time. Unlike the German colonists who came to the Volga region and other places, the Swedes who arrived from Hiiumaa were not voluntary settlers but had been exiled as punishment for refusing to work on the manors. J. Schleuning writes that of the I,20o people who were deported, barely half arrived. ${ }^{22}$ According to newer and specific data, 967 people left Hiiumaa, 352 of them children. However, the difficult journey and smallpox, which hit them on the road, claimed many lives and of the total only 535 arrived. ${ }^{23}$

For a long time, the Lutheran Church in Russia lacked a unified leadership, although attempts had already been made to establish one during the reign of Peter the Great. Then, on July 20, I819, Tsar Alexander I ordered the establishment of the General Consistory of the Lutheran Church, which occurred on October 25 of the same year. The Consistory was headed by a secular chairman and a spiritual vice-chairman, and the latter was appointed to be superintendent. For 13 years, the Consistory operated in Saratov, amid the large concentration of Germans in the Volga region. The General Consistory was then moved to Moscow ${ }^{24}$ and later to Saint Petersburg.

The Lutheran Church in Tsarist Russia was very closely connected with the country's Baltic provinces. With the new Church Act in 1832, the Orthodox Church became the state church while the Lutheran Church remained a locally permitted church. The Act caused the Lutheran Church in the Baltics to lose its autonomy, and it was subordinated to the General Consistory in Saint Petersburg, ${ }^{25}$ although it should be emphasised that clergy from the Baltics still dominated. On 28 December 1832 Emperor Nicholas I approved the statutes of the Russian Lutheran Church, which had been developed mainly by Baltic Germans. According to the statutes, the church was closely connected to the state. Lutheran Church life in Russia was managed by the General

2I Kreutschmar, G., Rathke, H. Evangelisch-Lutherische Kirche in Russland, der Ukraine, Kasachstan und Mittelasien. Der Bote, St. Petersburg, 1995, 6-7.

22 Schleuning, J. Die Stummen reden. 400 Jahre evangelisch-lutherische Kirche in Rußland. Martin Luther Verlag, Erlangen/Würzburg, 1952, 69-70.

23 Erelt, P. Hiiu rootslaste suurküüditamine. - Eesti Ekspress, I6 June 2005.

24 Schleuning, J. Die Stummen reden, 6o, 67.

25 Talve, I. Eesti kultuurilugu. Keskaja algusest Eesti iseseisvuseni. Ilmamaa, Tartu, 2004, 323-324. 
Consistory in Saint Petersburg and subordinated to the Ministry of Internal Affairs. The General Consistory continued to be headed by a secular chairman with the Emperor usually appointing someone from the Baltic nobility to fill the post. There was also an ecclesiastic deputy whose title was General Superintendent. In addition, there were two more secular and two more spiritual assessors in the General Consistory, the majority of which came from the Baltic Sea provinces. The importance of the Baltics in the General Consistory was great: six consistory districts were under the jurisdiction of the Baltics, while only two, i.e. the Saint Petersburg and Moscow consistory districts, covered the rest of Russia. ${ }^{26}$ The first of them, i.e. the Saint Petersburg Consistory, included the congregations from the Arctic Ocean in the north to the Black Sea in the south and from the Volhynia in the west to Central Russia in the east. The congregations in the eastern part of European Russia, Siberia, Central Asia and the Caucasus were subordinated to the Moscow Consistory, with the exception of the congregations of the German settlements in Georgia, which formed a separate synod. ${ }^{27}$

Most of the Lutheran pastors in Russia had graduated from the University of Tartu. Although most of them were Baltic Germans, there were also Estonians and Latvians, and as of the late nineteenth century, also German settlers in Russia. ${ }^{28}$ Many of the young men from the German settlements in Russia went to study in Tartu, studying in both the Theological as well as the other faculties. Finally, their number in Tartu was so large that they founded their own fraternity, called Teutonia, in 19I2, which included representatives from almost all the German settlements in Russia. ${ }^{29}$

26 Gesetz für die Evangelisch-Lutherische Kirche in Russland. Franz Kluge, Reval, 190I, 84; Amburger, E. Geschichte des Protestantismus in Rußland. Evangelisches Verlagswerk, Stuttgart, 196I, 77; Roemmich, H. Die evangelisch-lutherische Kirche in Rußland in Vergangenheit und Gegenwart. - Die Kirchen und das religiöse Leben der Rußlanddeutschen. Evangelischer Teil. Bearb. von Joseph Schnur. Landsmannschaft der Deutschen aus Rußland. Stuttgart, 1978, 17-18.

27 Gesetz für die Evangelisch-Lutherische Kirche in Russland, 75; Schleuning, J. Die Stummen reden, 9I; Die Evangelisch-Lutherischen Gemeinden in Russland. Eine historisch-statistische Darstellung. Bd I.: Der St. Petersburgische und der Moskowische Konsistorialbezirk. Watsar, St. Petersburg, 1909, III.

28 Roemmich, H. Die evangelisch-lutherische Kirche in Rußland, I, I4.

29 Schleuning, J. Die Stummen reden, 86-87. 


\section{LUTHERANS IN THE CAUCASUS}

The arrival of Lutherans in the Caucasus is directly related to tsarist colonisation policy. In I804, immediately after the annexation of Georgian territories to Russia (I8or), Emperor Alexander I invited German colonists to settle in the Black Sea region and the South Caucasus. ${ }^{30}$ The first German settlers arrived in Georgia in I8I7. Factors that influenced their arrival were the recent Napoleonic Wars and associated famine, although the reasons could also have been religious. Most of the newcomers were Lutherans from southern Germany and Switzerland. Many of them were followers of Pietism, especially of the so-called Württemberg Pietism, which had contradicted orthodox Lutheranism. When the consistory of the Lutheran church in Württemberg replaced old songbooks and catechisms in the early igth century, many left the church in protest and began baptizing the children themselves. They only acknowledged the church liturgy of Württemberg, the old Württemberg songbook, and some other familiar and reliable customs. ${ }^{31}$ Many were inspired to relocate by the prophecies of Jesus' Second Coming and his I,ooo-year reign on Earth. It was believed that the end of the world should be faced in the Caucasus, atop Mount Ararat. ${ }^{32}$

Through typical chain migration, the German Lutheran population multiplied in subsequent years. The Pietists distanced themselves from the ecclesiastical organisation and ordained clergy, preferring to choose pastors from among their own group. Some success among the German settlers was achieved by missionaries from the Basel Missionary Society, who had worked to convert the local Muslims to Christianity. Now they also undertook the spiritual care of the German colonists. However, for a long time the German colonists there did not want to recognise the pastors sent from Russia. The first clergyman who graduated from the University of Tartu was not able to start working in this difficult area until I854. Eventually, the German settlements in the Caucasus succeeded in creating a church structure and to obtain government approval for it. However, the settlers were allowed to retain their unique liturgical features. Organisationally, the entire region remained ecclesiastically autonomous, not subject to any consistory. It reported

30 Himmel, G. Deutsches Kulturerbe in Georgien - Geschichte, Gegenwart und Zukunft. - Deutsch in Georgien. Bd. 2. Hrsg. von H. Glück, F.-H. Nielsen, M. Paitschadse. CollibriVerlag, Bamberg, 2000, 73.

3I Hoffmann, P. Die deutschen Kolonien in Transkaukasien. Verlag von Dietrich Reimer, Berlin, 1905, 2, 28.

32 Kokoev, K., Svanidze, G., Melikishvili, L. National Minorities in Georgia. UNHCR, Tbilisi, I999, 23. 
directly to the Ministry of Internal Affairs, and its Department of the Spiritual Affairs of Foreign Confessions. Their church was a separate organisation, i.e. the Evangelical Lutheran Synods of the South Caucasus, headed by a high pastor appointed by the Deputy Governor of the Caucasus. The pastor of the colonial congregation resided in Tbilisi. From I865 to I884, this was Karl Rudolf Roos, who was born in Tallinn. It is noteworthy that the synod of the South Caucasus were united with the Russian Lutheran Church until the last General Lutheran Synod, which was held in 1928 in Moscow, i.e. at a time when a general attack on religion had begun in the Soviet Union. However, in the nineteenth century it maintained its independence. ${ }^{33}$

Tbilisi was home to a large number of Lutheran officials and soldiers who did not go along with the separatism of the local German colonists. They formed a separate Lutheran congregation in Tbilisi, which built its own house of worship and school in 1850 . Unlike the Tbilisi colonial congregation, it recognised the Russian Lutheran Constitution from 1832 and belonged to the consistory of Moscow. ${ }^{34}$

In I866, four parishes, i.e. Tbilisi, Stavropol, Pyatigorsk and Yeysk, belonged to the Moscow Consistory District of the North and South Caucasus. ${ }^{35}$ In the I89os, at a time when Estonian settlements had already been established in Abkhazia, a number of changes took place in the Lutheran administration of the North and South Caucasus that directly affected the church life of the local Estonians. Specifically, in the late nineteenth and early twentieth centuries, Abkhazia was divided between two different administrative centres. The Sukhum district, together with the Estonian villages of Alam-Linda and Ülem-Linda and Estonia, was initially part of the Kutais Governorate, and under the direct authority of the Deputy Governor of the Caucasus residing in Tbilisi, and thereby part of the South Caucasus. On the other hand, the Estonian villages of Salme and Sulevi in northern Abkhazia belonged to the Sochi district of the Black Sea Governorate.

33 Schleuning, J. Die Stummen reden, 76-78, 86; Amburger, E. Geschichte des Protestantismus in Rußland, 73, 130-I31; Amburger, E. Die Pastoren der evangelischen Kirchen Rußlands vom Ende des I6. Jahrhunderts bis 1937. Ein biographisches Lexikon. Institut Nordostdeutsches Kulturwerk/Martin-Luther-Verlag, Lüneburg/Erlangen, 1998, $26,153,450$.

34 Die Evangelisch-Lutherischen Gemeinden in Russland. Bd. I, 72.

35 Die Evangelisch-Lutherischen Gemeinden in Russland. Bd. I, VII. 


\section{THE VILLAGES OF SALME AND SULEVI IN YEKATERINODAR- NOVOROSSIYSK PARISH}

In the I88os, when the Estonian villages of Salme and Sulevi were founded, only one pastor served the entire North Caucasus. Initially he resided in Stavropol and, as of I886, in Vladikavkaz. The pastor's assignment was to visit every Lutheran settlement in the area at least once a year. ${ }^{36}$ Pastor Conrad Raimund Freifeldt was the first to visit the settlers of Salme and Sulevi, in i885. Freifeldt was born in Tartu in I847 and had been educated as a theologian at the University of Tartu. He had been a deacon of St. John's Church in Tartu and pastor of the Estonian St. John's Church in Saint Petersburg from I877 to I88o. He was later promoted to the General Consistory (I887-I892), but it seems that even then he visited the Estonian settlements, whenever possible, to perform services and visited Salme and Sulevi once a year. ${ }^{37}$ Needless to say, in I892 Freifeldt became general superintendent of the Lutheran Supreme Consistory of Russia. ${ }^{38}$

In I891, a vicar pastor was ordained to serve the western region of the North Caucasus, and by 1895 his service area had already transformed into a separate Yekaterinodar-Novorossiysk parish. By I894, the position of assistant to the pastor of Stavropol had been established in Vladikavkaz, which was transformed in 1905 into the position of separate parish pastor of Vladikavkaz. ${ }^{39}$

The Yekaterinodar-Novorossiysk parish included the Black Sea Governate and the districts of Maikop, Ladinsky and Kavkasky in the Kuban Governorate. ${ }^{40}$ Thus, it also included the villages of Salme and Sulevi in Abkhazia, together with several Estonian and German villages in the North Caucasus.

Adrian Alexander Wilhelm Schultz, a man born in Kullamaa (western Estonia) and educated as a theologian in Tartu, came to serve

36 Die Evangelisch-Lutherischen Gemeinden in Russland. Bd. I, 63; see also E. M. Armastus on üks tugev side. Sónumed Kaukaasia maalt. A. Mickwitz, Tallinn, I889, I3.

37 Kône tekst Salme küla 50 aastaseks juubeliks. I934. Eesti Ajaloomuuseum (EAM), 284.I.23, 3; Amburger, E. Die Pastoren der evangelischen Kirchen Rußlands vom Ende des 16. Jahrhunderts bis 1937. Ein biographisches Lexikon. Institut Nordostdeutsches Kulturwerk/ Martin-Luther-Verlag, Lüneburg/Erlangen, 1998, 317.

38 Amburger, E. Die Pastoren der evangelischen Kirchen Rußlands, 317; see the online-resource Erik-Amburger-Datenbank. Ausländer im vorrevolutionären Russland, URL: https:// amburger.ios-regensburg.de/index.php? mode $=4$ \&letter $=F$ (last accessed I8 December 2020).

39 Die Evangelisch-Lutherischen Gemeinden in Russland, Bd. I, IX.

40 Die Evangelisch-Lutherischen Gemeinden in Russland, Bd. I, 63. 
in the region in $189 \mathrm{I}$ as vicar pastor. He had previously been an assistant pastor in Haljala, then served in various parts of Russia. ${ }^{41}$ Arriving in the North Caucasus, his task was to serve most of the areas of the Kuban and Black Sea Governorates, which were scheduled to become YekaterinodarNovorossiysk parish. Schultz resided in Novorossiysk, and when the parish of Yekaterinodar-Novorossiysk was formed in 1895 , Schultz was chosen as its pastor. Due to the large size of the parish, the congregation of Yekaterinodar wanted autonomy therein, and in 1897 the position of Yekaterinodar assistant pastor was established..$^{42}$ In 1909, without including the area of Yekaterinodar, there were 3,50o people in the parish, 2,400 of them German, I,050 Estonian and is Latvian. There were 500 Estonians in the parish of Salme, 500 in Sulevi, I5O in Esto-Sadok, 40 in Burnoye and five elsewhere. However, there were also Estonians in the centre of the parish in Novorossiysk, where the pastor of the Church of Peter and Paul held services in both German and Estonian. ${ }^{43} \mathrm{He}$ also gave religious education lessons to German and Estonian children in his apartment. ${ }^{44}$

The residents of Salme and Sulevi villages remembered Pastor Schultz later as a kind and honourable man who won the hearts of the villagers and who's arrival was always anticipated with longing. As an active hunter, he impressed the local hunters by helping them acquire rifles and ammunition from Novorossiysk. ${ }^{45}$ It seems that the admiration was mutual. In the documentations of the Russian Evangelical Lutheran Church in I9OI the pastor praised the religious zeal, literacy and biblical knowledge of the Estonian community of Novorossiysk parish as being much above other settlers' qualities. ${ }^{46}$ The following year, the pastor praised the Estonian confirmation class of Krasnaya Polyana, who provided him much more joy than the Germans because they read so well and expressively and answered all his questions intelligently. The pastor emphasised that these were children taught only by their parents and had no formal religious instruction. ${ }^{47}$ However, the report shows that the pastor was worn out because he did not have separate residences in the

4I Amburger, E. Die Pastoren der evangelischen Kirchen Rußlands, 467.

42 Die Evangelisch-Lutherischen Gemeinden in Russland, Bd. I, 63.

43 Die Evangelisch-Lutherischen Gemeinden in Russland, Bd. I, 64-65.

44 Jahresbericht des Kirchenrats der evangelisch-lutherischen Gemeinde zu Novorossiisk 19I3. Buchdruckerei August Mickwitz, Reval, 1914, 3.

45 Ludvik, V. Sulevi küla ajaloost. EAM 284.I.39, I4-I5; see also Sulevi ja Eesti asundusest Kaukasias. - Postimees, 1917, 199, I-2.

46 Die evangelisch-lutherische Kirche Russlands im Werk ihrer Unterstützungs-Kasse im Jahre I90I. Watsar, St. Petersburg, 1902, 75.

47 Die evangelisch-lutherische Kirche Russlands im Werk ihrer Unterstützungs-Kasse im Jahre 1902. Watsar, St. Petersburg, 1903, 69. 
villages and had to spend the night in a settler's dwelling, often in the same room with a large family. ${ }^{48}$ Schultz also complained about tiring and dangerous journeys he had to make to the settlements, because the area was mountainous, the journey difficult, and the local Greeks and Kabards in the northern parts of the parish made the journey dangerous. ${ }^{49}$ However, Schultz, as an authoritative man of the people, was probably responsible for more than sixty Orthodox Estonians returning to the Lutheran Church in the early twentieth century. ${ }^{50}$

Then Schultz was transferred to Stavropol, after which between 1908 and 1913 a new pastor, Hermann Girgensohn, who was appointed to Novorossiysk, served the settlements. Girgensohn was born in Noarootsi (western Estonia) the son of a pastor, graduated from Cathedral School (Toomkool) in Tallinn and the Faculty of Theology at the University of Tartu. ${ }^{51} \mathrm{He}$ had been the pastor in Reigi from 1895 to 190I, thereafter, from 190I to 1906, in Rapla. However, while serving in Rapla something happened that tarnished his reputation, and continued to haunt him even after he was sent to the Caucasus. It is known that during the Russian Revolution of 1905, the revolutionaries demanded weapons from pastors, as well as any money that might have been in the congregation's coffers. Money was also demanded from Hermann Girgensohn at the time. ${ }^{52}$ For one reason or another, he later complained to the leaders of the penal squads, whereupon several men who had taken part in the revolution were either shot or suffered corporal punishment. In the early spring of 1906, an assassination attempt was made on Girgensohn and he was struck by a bullet. The shooter was not identified, the pastor lost one eye and later left Rapla. ${ }^{53}$

When he became pastor of Novorossiysk in 1908 and began serving the Estonian settlements, among others, rumours about his background soon reached the settlers, of course affecting his reputation. Girgensohn was considered arrogant and proud and did not develop close relations with the settlers. ${ }^{54}$ In I9I2, he was not even received by some of the settlements in the Sukhum region. ${ }^{55}$ The church reports from 1913 complained

48 Die evangelisch-lutherische Kirche Russlands im Werk ihrer Unterstützungs-Kasse im Jahre 1906. Watsar, St. Petersburg, 1907, 77.

49 Die evangelisch-lutherische Kirche Russlands im Werk ihrer Unterstützungs-Kasse im Jahre 1903. Watsar, St. Petersburg, 1904, 65.

so Die evangelisch-lutherische Kirche Russlands im Werk ihrer Unterstützungs-Kasse im Jahre 1906, 77 .

5I Amburger, E. Die Pastoren der evangelischen Kirchen Rußlands, 323.

52 Karjahärm, T. I905. aasta Eestis. Massiliikumine ja vägivald maal. Argo, Tallinn, 2013, I56.

53 Aitsam, M. 1905. aasta revolutsioon ja selle ohvrid Eestis. Ilmamaa, Tartu, 20II, I69, 392.

54 Ludvik, V. Sulevi küla ajaloost. EAM 284.I.39, I4-I5; Holberg, H. Estonia kiriku ja hariduse ajalugu. 9.oI.I919. Eesti Kirjandusmuuseumi Kultuurilooline Arhiiv (EKLA), 235.27.II, I.

55 Sommer, S. Alam-Linda asunduse ajaloost. EKLA 235.26.2, 17. 
that very few Estonians attend services in the Novorossiysk church, and that their participation was also a problem in other parts of the governorate. ${ }^{56}$ After the Bolsheviks seized power in Russia, Girgensohn did not return to Estonia but moved to Germany, where he died in 1922 at the age of $55 .{ }^{57} \mathrm{His}$ negative reputation persisted in the Estonian settlements for decades to come. In the autumn of 1980, one of his former confirmation students told a Estonian collector of folk traditions in the village of Sulevi, that Girgensohn had his son hanged in Estonia for courting a girl. ${ }^{58}$ We can see that as the story of pastor Girgensohn has become folklore, it has become increasingly embellished.

\section{THE VILLAGES OF ALAM-LINDA, ÜLEM-LINDA AND ESTONIA IN THE PARISH OF BATUM-KUTAIS}

In the South Caucasus, the organisation of the Lutheran Church in the nineteenth century was originally linked to the Tbilisi congregation. However, the rapid economic development of the area meant a large influx of people, including Lutherans, which also led to changes in the church administration. If initially the pastoral care of the Tbilisi pastor covered the entire Transcaucasus, with the exception of the independent Georgian colonial congregations that had their own synod, then the developing oil industry in $\mathrm{Baku}$ and the continuing agrarian colonisation in other regions necessitated additional manpower. In I883, Baku parish was formed separately from Tbilisi parish to serve the eastern parts of the South Caucasus. ${ }^{59}$

Of course, Estonians (officials, scientists, workers, maids, etc.) also lived in Tbilisi and initially, before an Estonian society was formed at the end of the first decade of the twentieth century, the only gathering place for Estonians was the church, where Estonian-language services were held every other Sunday. Estonians also served on the church council. ${ }^{60}$ At the beginning of the twentieth century, services in Tbilisi were held in German, Russian, Estonian, Armenian and Latvian. ${ }^{61}$ When a new

56 Jahresbericht des Kirchenrats der evangelisch-lutherischen Gemeinde zu Novorossiisk I9I3, 2.

57 Amburger, E. Die Pastoren der evangelischen Kirchen Rußlands, 323.

58 Truupôld, A. Kilde eestlaste elust endistes Kaukaasia asundustes. 1980-1981. Eesti Rahva Muuseumi korrespondentide vastused (ERM KV), 362.206.

59 Die Evangelisch-Lutherischen Gemeinden in Russland, Bd. I, 74.

60 Tiflisi Eesti asundus. - Päevaleht, I9II, I22, I; O.T.K. Tiflisi Eesti asundus. - Päevaleht, I9I2, 9I, I.

6I Die evangelisch-lutherische Kirche Russlands im Werk ihrer Unterstützungs-Kasse im Jahre I90I, 63 . 
Latvian pastor took over in Tbilisi in 1904, Estonians were left without Estonian-language services. However, the Latvian pastor promised to quickly learn Estonian ${ }^{62}$ and, as we can see from the next church report in 1905, the pastor's efforts bore fruit and Estonians were again served in Estonian. ${ }^{63}$

However, the main Estonian settlements in Tbilisi parish were the Estonian villages of Estonia, and Alam-Linda and Ülem-Linda around Sukhum. Pastor Ferdinand Konstantin Ludwig Hoerschelmann, who had just become the pastor of Tbilisi in November I883, visited the village of Estonia shortly after its foundation. Born in Estonia, he spoke Estonian, although was a German. ${ }^{64}$ Hoerschelmann, who is fondly remembered in the Estonian settlements, also visited them in 1885 . Since there were no churches in the villages, the services took place in settlers' homes or, in good weather, outdoors under the trees. In I887, Hoerschelmann was appointed a pastor in the Taurida government, and Christoph Wilhelm Beermann, who also took paternal care of the settlers, began to serve these settlements. ${ }^{65}$ In addition to coming from Estonia and studying theology at the University of Tartu, he was also an Estonian by nationality, born in 1864 in Póltsamaa. In I888 he became the assistant pastor of the Tbilisi colonial congregation. It should also be noted that several decades later, in 1920, Beermann became the provost of Järva. ${ }^{66}$

In 1892 , a permanent position of assistant pastor was established in Batum to serve the western portion of the South Caucasus, the area of service of which included Batum, Kutais, Poti, Sukhum and the German settlements of Gnadenberg and Neudorf, which emerged near Sukhum, as well as the Estonian settlements of Alam-Linda, Ülem-Linda and Estonia. Wilhelm Heine, a man with an extremely interesting life, was appointed assistant pastor. ${ }^{67}$ His father was a German born in Taurida Governorate, who became a missionary and worked in many exotic lands. His son Wilhelm was born on the island of Sumatra, although the Estonian settlers in the Caucasus mistakenly remember him as being born in Ceylon. ${ }^{68}$ However, these two islands are in the same direction from

62 Die evangelisch-lutherische Kirche Russlands im Werk ihrer Unterstützungs-Kasse im Jahre I905. Watsar, St. Petersburg, 1906, 65.

63 Die evangelisch-lutherische Kirche Russlands im Werk ihrer Unterstützungs-Kasse im Jahre I906, 75.

64 Raunam, H. Eestlaste asumine Kaukaasiasse. 1944. EAM 281.I.I8, 9; Sommer, S. AlamLinda asunduse ajaloost. EKLA 235.26.2, I5.

65 Sommer, S. Alam-Linda asunduse ajaloost. EKLA 235.26.2, I5; M. G. Suhum-Kaleest. Postimees, I893, 36, 2.

66 Amburger, E. Die Pastoren der evangelischen Kirchen Rußlands, 258.

67 Die Evangelisch-Lutherischen Gemeinden in Russland, Bd. I, VII-VIII.

68 H. Holberg. Estonia kiriku ja hariduse ajalugu. 9.0I.1919. EKLA 235.27.II, I. 
Abkhazia. Wilhelm lived there until he was seven years old. Then the family arrived in Estonia. Wilhelm graduated from high school in Pärnu and the Faculty of Theology at the University of Tartu. In I89r he was ordained in Tbilisi and for the next two years he was the assistant pastor in Batum, from where he also travelled to the Estonian settlements. ${ }^{69}$ Heine conducted his first services with Estonians in Russian, but then he stayed in Estonia village for a few months where, according to the settlers, by 1892 he already spoke "lucid Estonian". ${ }^{70}$

In 1894 , the Batum-Kutais church parish was organised, which included the Estonian villages in the Sukhum region. ${ }^{71}$ The pastor resided in Batum, where there was a larger German congregation and also some Estonians. From I894 to I9Io, the pastor of the Batum congregation was Arthur August Oskar Bernhoff, who according to some settlers was Estonian. ${ }^{72}$ Whether he was Estonian or Baltic German is not quite clear. Erik Amburger, in his review of the pastors who served Lutheran congregations in Russia, always emphasises if a pastor is non-German, but does not do so in Bernoff's case. ${ }^{73}$ Bernhoff probably spoke Estonian so fluently that the Estonian settlers thought he was Estonian. Bernhoff was born in 1869 in Tartu, where he graduated from secondary school ${ }^{74}$ and the Faculty of Theology at the University of Tartu. Later he was in the register of the German congregation in Rakvere. ${ }^{75}$ In I894 he was ordained an assistant pastor of the newly founded Batum-Kutais parish, and in 1898 , as the pastor. ${ }^{76}$ Estonian settlers remember Bernhoff as a good man who took paternal care of the settlers. Unlike previous pastors, he started visiting the Estonian settlements twice a year. However, this is understandable because they now comprised a separate parish. Moreover in 1905, during Bernhoff's tenure, the Estonian and German villages near Sukhum were merged into a separate auxiliary congregation of the Batum-Kutais congregation. ${ }^{77}$ According to the annual reports of Batum-Kutais parish, the pastor's spring visit took place in

69 Amburger, E. Die Pastoren der evangelischen Kirchen Rußlands, 342.

70 Holberg, H. Estonia kiriku ja hariduse ajalugu. 9.oI.1919. Sommer, S. Alam-Linda asunduse ajaloost. EKLA 235. 27.II, I; Pihlakas, J. Suhhumis. - Sakala, I892, 5, 3.

7 I Sommer, S. Alam-Linda asunduse ajaloost. EKLA 235.26.2, I6.

72 Pint J. Mälestusi Musta mere ranniku eestlaste elu-olust. 1938. EAM 284.I.II, 26; Pihlakas, J. Kirjad Kaukasiast. - Virulane, 1906, I2I, 2.

73 Amburger, E. Die Pastoren der evangelischen Kirchen Rußlands, 262.

74 Arthur August Oskar Bernhoff. Rahvusarhiiv, Eesti Ajalooarhiiv (RA, EAA), 402.2.1742, 3.

75 Eesti Evangeelse Luteriusu Kiriku Konsistooriumi Arhiiv (EELKKA), 28.I.5.I3a.

76 Amburger, E. Die Pastoren der evangelischen Kirchen Rußlands, 262.

77 Ülem-Linda ajalugu. EKLA 235.30.5, 5; Die Evangelisch-Lutherischen Gemeinden in Russland, Bd. I, 84; Die evangelisch-lutherische Kirche Russlands im Werk ihrer Unterstützungs-Kasse im Jahre I905. Watsar, St. Petersburg, 1906, 67. 
the second half of June before or on Midsummer's Day and in autumn in November. ${ }^{78}$

In the city of Sukhum, Estonians attended the German-language services of the German congregation. At the turn of the century, there were about Ioo people in the city's congregation. ${ }^{79}$ In 1903, Pastor Bernhoff gave his first sermon in Estonian in the newly built home of Estonian Jakob Mihkelson and gave the people the Holy Communion. ${ }^{80}$ Jakob Mihkelson was also a member of the council of the Lutheran congregation in Sukhum as of January 1904. ${ }^{81}$ Just as in the Estonian settlements, Pastor Bernhoff also received frequent praise from the Germans in the Batum congregation. ${ }^{82}$ When, in 1902, the congregation of the Batum Evangelical Church received a leather-bound Bible with the donor's dedication from the German Empress Augusta Victoria via the German Embassy in Saint Petersburg, Pastor Bernhoff's contribution to the spiritual service of the local German citizens was also mentioned. ${ }^{83}$ Bernhoff's activity went beyond the fulfilment of his ecclesiastical duties. For example, he gave lectures to the congregation in Batum about the biblical creation narrative, as well as about Babylon, Buddha, Nietzsche, Luther, and the meaning of life. He also introduced scientific theories about the origin of the Earth, Darwin's teachings, etc. ${ }^{84}$

Then, in I9II, Pastor Bernhoff was transferred to the city of Tambov and the congregation was left without a pastor for several years. ${ }^{85}$ However, Bernhoff continued to remember his congregation with a good word. For example, he sent a greetings telegram from Tambov to the 1914 Estonian Song Festival in Sukhum. ${ }^{86}$ But the congregation still had no pastor, although a Lutheran pastor from Novorossiysk did start to visit Batum and the other parish centres including the Estonians villages. ${ }^{87}$ From I9II to 1913, the aforementioned Hermann Girgensohn, the pastor at the Novorossiysk Lutheran Church, served the settlements, although

78 Очет о работе евангелическо-лютеранских приходов в Кутаиской губернии и Батумской области с І. окт. 1908 - І. окт. 1909 г. National Archives of Georgia, Kutaisi Central Archive (NAG, KCA), II4.I.5, I.

79 Die Evangelisch-Lutherische Kirche Russlands im Werk ihrer Unterstützungs-Kasse im Jahre I899. W. Zoberbier, St. Petersburg, 1900, 23.

8o Eestlaste ajalugu Suchumi linnas. EKLA 235.29.I4, Io.

8I Eestlaste ajalugu Suchumi linnas. EKLA 235.29.I4, II.

82 Bericht des Kirchenrats der Evangelisch-Lutherischen Gemeinde in Batum für das Jahr 1904. H. Laakmann, Jurjew, 1905, 4.

83 Bericht des Kirchenrats der Evangelisch-Lutherischen Gemeinde in Batum für das Jahr 1902. H. Laakmann, Jurjew, 1903, 3.

84 Bericht des Kirchenrats der Evangelisch-Lutherischen Gemeinde in Batum für das Jahr 1908. H. Laakmann, Dorpat, 1909, 5.

85 Die evangelisch-lutherische Kirche Russlands im Werk ihrer Unterstützungs-Kasse im Jahre 1913. St. Petersburg, 1914, 59.

86 Kider, K. Kaukasi-Eesti asunduste juubeli-laulupidu Suhumis. - Olevik, 1914, 64, 2.

87 Ülem-Linda ajalugu. EKLA 235.30.5, 5 . 
he was not as popular as Bernhoff. His visits were also now much less frequent due to the long distances.

During the first decade of the twentieth century, the proportion of Estonians in Batum-Kutais parish was significant. In 1907, 54 children were baptised in the congregation and judging by their names at least i 8 of them were Estonian. In the same year, 37 were confirmed, 18 of whom were Estonian and five of the is weddings were organised for Estonians. In Batum, the congregation had 303 members (mainly German), while in Sukhum, in addition to 44 Germans and two Latvians, there were I9 Estonians in the congregation. In the Estonian villages, the Estonians naturally comprised an overwhelming majority (270 Estonians in Estonia; 159 Estonians in Alam-Linda, along with I2 Latvians; II8 Estonians in Ülem-Linda, along with 20 Latvians). However, there were also Estonians, for example in the German village of Neudorf (25 Estonians along with 178 Germans) ${ }^{88}$ There were more members in the villages than in Batum and other cities in the parish. This is illustrated by the number of people who partook of the Holy Communion between I September 1908 and I September 1909: 48 men and 47 women in Batum; 80 men and 92 women in Gnadenberg-Neudorf; 24 men and 27 women in Ülem-Linda; 42 men and 44 women in Alam-Linda; 80 men and 70 women in Estonia; 4 men and 7 women in Kutais; 6 men and I2 women in Sukhum; I man in Semekalovka; 2 men and 5 women in Poti; and 4 men and 2 women in Abastumani. ${ }^{89}$

The list reveals a fact that is also emphasised in the pastor's reports: in the first decade of the twentieth century, the focus of the Batum-Kutais parish was not Batum, but the villages. Initially, the church leadership hoped that, over time, the congregations would become more closely merged with the Batum centre, but this remained a pious wish. The branch congregations had their own church councils and a great deal of independence. ${ }^{90}$

88 Bericht des Kirchenrats Evangelisch-Lutherischen Gemeinde in Batum für das Jahr 1907. NAG, KCA II4.I.4, 7-9.

89 Очет о работе евангелическо-лютеранских приходов в Кутаиской губернии и Батумской области с І. окт. 1908 - I. окт. 1909 г. NAG, KCA II4.I.5, 2.

90 Bericht des Kirchenrats Evangelisch-Lutherischen Gemeinde in Batum für das Jahr 1907. NAG, KCA II4.I.4, 4. 


\section{THE ROLE OF THE PARISH CLERK/ SCHOOLTEACHERS IN THE CONNECTION TO THE HOMELAND}

The most important ecclesiastical services were conducted in the settlements by a pastor who, as mentioned above, visited the congregations once or twice a year - he confirmed young people, gave the Holy Communion and married couples. Because the pastors seldom visited the congregations, the parish clerk/schoolteachers in the settlements promoted religious life locally. They were generally hired from Estonia or Estonian settlements in Russia. In the second half of the nineteenth century and early twentieth century, the Estonian press often published appeals from Estonian settlers living in various parts of the tsarist state, in order to find people who were educated and ready to promote the religious and education life of the settlements. Input and fresh blood were sought from the homeland, which would stimulate religious life in the settlements. At times, the locals would ask the parish pastors to help them find school teachers, ${ }^{91}$ which shows how closely the churches and the schools in the settlements were connected.

In Estonia, education was also connected to the Lutheran Church. Back in the mid-nineteenth century, in both Estonian and Livonian governorates, the priorities at the level of rural municipality and manor schools were learning the catechism as well as knowing Bible stories, hymns and reading, while writing and arithmetic were to be taught "if possible". Until the second half of the I86os, there were no uniform rules in Lutheran rural municipality and manor schools that would have determined how many hours a day had to be devoted to one subject or another. The relevant instructions were given to the teachers by the local pastors, ${ }^{92}$ which, of course, meant the dominance of religious subjects. At the same time, when talking about the profession of the parish clerk/schoolteachers, the concept was still in use in nineteenth century Estonia, although it had largely lost its former meaning and become a colloquialism. In any case, the Peasants' Act of i8r9 already recognises rural municipality and parish schools (not parish clerk schools), school teachers and parish school teachers. The change in the content of the concept is also characterised by the fact that the Jānis Cimze seminary, which had previously educated parish clerk/schoolteachers, was initially

\footnotetext{
9I Suhumist. - Walgus, I890, 42 (Io October I890), 3.

92 Laul, E. Alghariduskoolid I860.-I88o. aastail. - Eesti kooli ajalugu II köide. Koost. E. Laul. Teaduste Akadeemia Kirjastus, Tallinn, 2010, 137-139, I46.
} 
called a parish clerk school, although from the late i87os at the latest, it was a seminary for parish school teachers. A schoolteacher in Estonia could also perform the duties of a parish clerk, but there was no great need for this. After all, the pastors of the parishes were on the site and could conduct liturgical services and administer the sacraments. The story was different with the Estonian settlements established in different parts of the tsarist state, where school teachers were also expected to perform the duties of parish clerk..$^{93}$ Therefore, they were called parish clerk/ schoolteachers. ${ }^{94}$ Their office embodied responsibility and authority and they played an important role in the church and school lives of the settlement. The parish clerk/schoolteacher had to be the leader of settlement life in many areas of activity. In the scattered parishes, which the pastor might visit only once or twice a year due to the large distances, the parish clerk/schoolteacher acted as the pastor's assistant and deputy in almost every capacity. Organised church life and the Christian upbringing of youth were unthinkable without him. The parish clerk/ schoolteacher conducted reading services, and was the organist. He baptised children, buried the dead, was the religious teacher and taught Confirmation classes. He maintained the church register and visited the sick. ${ }^{95}$ In addition to his pedagogical and clerical work, the parish clerk/schoolteacher conducted the choirs and brass bands, organised theatre groups, etc. ${ }^{96}$ In the Estonian settlements in Abkhazia, the parish clerk/schoolteachers conducted reading services every Sunday ${ }^{97}$ or twice a month. ${ }^{98}$ However, as the reports of the parish clerk/schoolteachers indicate, the total number of church services, including funerals, etc., was over sixty per year. ${ }^{99}$ Apparently we have to agree with Jüri Meomuttel, who writes that the parish clerk/schoolteachers had a greater influence and importance in these settlements than their counterparts did in their homeland. Often, they were the only well-educated people in the settlements ${ }^{100}$ and mediated the cultural impulses of the homeland to the

93 See, for example, M. G. Suhum-Kaleest. - Postimees, I893, 36, 2; Suhhumi eestlaste elu üle II. - Postimees, I894, I06 (17 May I894), 2.

94 See, for example, Chr. Suhhumist. - Postimees, I899, 260 (23 November I899), 3; J. T. Suhhum-Kaleest. - Eesti Postimees, I896, I2 (22 March I896), 3;

Kiri Suhum-Kaleest. - Eesti Postimees, 1903, 38, I.

95 Roemmich, H. Die evangelisch-lutherische Kirche in Rußland, 30-31; Pihlakas, J. Kirjad Kaukasiast. - Virulane, 1906, I2I, 2.

96 Olevik, I89I, I5, 309-3IO; Tallinna Teataja, 1914, 47, I; Nigol, A. Eestlaste asundused ja asupaigad Venemaal. Postimees, Tartu, I918, 83.

97 Pint J. Mälestusi Musta mere ranniku eestlaste elu-olust. EAM 284.I.II, 25; Die EvangelischLutherischen Gemeinden in Russland, Bd. I, XII.

98 Muga. Salme ja Sulevii asundusest. - Perekonnaleht, I912, 45, 356.

99 Очет о работе евангелическо-лютеранских приходов в Кутаиской губернии и Батумской области с І. окт. 1908 - I. окт. 1909 г. NAG, KCA II4.I.5, I.

ıоo Meomuttel, J. Eesti asunikud laialises Vene riigis, 5. 
settlements. They published surveys about life in the settlements in the Estonian press, ordered literature from Estonia, used works by Estonian writers in the repertoire of the theatre groups, and works by Estonian composers in the choirs and brass bands. In particular, the parish clerk/ schoolteachers were the mediators of transnational connections between the settlements and the homeland. Frequent rotations facilitated this in every way, with their terms of office usually lasting three years. Some stayed for a second term, but very many went to Estonia or other Estonian settlements outside Estonia. Some later returned to the area where they had previously served. An important connection with the homeland was established by the fact that the parish clerk/schoolteachers used Estonian textbooks in their teachings. Mihkel Kampmann's Kooli lugemiseraamat (School Reader) ${ }^{101}$ was still being used in the Estonian settlements in the Caucasus in the early I920s. ${ }^{102}$

Separate church buildings, like those in the Livonia and Allmäe settlements of the North Caucasus, did not exist in the Estonian settlements of Abkhazia. In Alam-Linda and Ülem-Linda, a classroom served as the church. In Estonia, there was a separate room in the school building for church services. The construction of combined school and houses of worship was common in the smaller Lutheran settlements of the tsarist state. ${ }^{103}$ This was also due to the church's funding model, the ideological roots of which dated back to the sixteenth century. Even then, schools were considered an integral part of the Lutheran Church, for which the congregations were responsible. ${ }^{104}$ This had been the case in Estonia, and in the nineteenth century it was still the case in the Estonian settlements outside Estonia. The settlement schools were children of the church. Teaching and worship in the mother tongue, which went hand in hand in Protestant countries, also became characteristic of the Estonian settlements as they progressed. The literacy level of Lutherans, which was higher than the rest of the local population, ${ }^{105}$ can be explained by the Lutheran tradition that placed great importance on religious-pedagogical

\footnotetext{
IoI Kampann, M. Kooli lugemiseraamat: I.-3. kooliaasta. M. Martna, Tallinn, I905.

IO2 Sabbo, H. Võimatu vaikida I. Ühistöö, Tallinn, 1996, 17I-172.

I03 Roemmich, H. Die evangelisch-lutherische Kirche in Rußland, 25.

I04 Schleuning, J. Die Stummen reden, 92-93.

I05 In 1897 , the literacy rate was 78.7 percent for Russian Germans (Baaden, A. AussiedlerMigration. Historische und aktuelle Entwicklungen. Spitz, Berlin, 1997, 29), 88-90 percent for Estonians, and 82 percent for Latvians (Kulu, H. Eestlaste tagasiränne 1940-1989. Lääne-Siberist pärit eestlaste näitel. Tartu Ülikooli Kirjastus, Tartu, I997, II8), compared with only Iо-Is percent on average in some regions of Russia (Очерки истории школы и педагогической мысьли народов СССР. Конец XIX - начало XX в. Отв. ред. Е. Д. Днепров. Педагогика, Москва, 1991, 4I5-416). According to the 1926 census, Estonians were in fourth or fifth place in the Soviet Union in terms of literacy after Karaites, Latvians, Czechs/Slovaks. See Maamägi, V. Uut elu ehitamas. Eesti vähemusrahvus NSV Liidus (1918-1940). Eesti Raamat, Tallinn, 1980, 70.
} 
work. On the other hand, it also led to education with a relatively clerical orientation. The congregation that established the school also hired the school teacher, who in turn also served as parish clerk. When, in I88I, the Lutheran schools of the Russian empire were subordinated to the Ministry of Public Education and the principals of the provincial public schools and their subordinate inspectors started exercising supervision over the schools, in practice, the congregations retained their influence over the schools. ${ }^{106}$ In the area under examination, i.e. the Caucasus, the Lutheran schools were subordinated to the Ministry of Education even later, in $1892 .{ }^{107}$ However, this did not mean that the church lost its influence over the schools. The financing model practiced in the Lutheran Church played an important role therein. Although the settlers had a financial responsibility to develop church and school life, the church's centrally run fund provided additional resources.

\section{RELIEF FUND FOR THE SUPPORT OF CHURCH LIFE IN THE SETTLEMENTS}

The Lutheran Church provided financial support for the spiritual life of the settlements through the Relief Fund for Lutheran Parishes in Russia (Unterstützungs-Casse für Evangelisch-Lutherische Gemeinden in Russland), which was founded in 1859 . The initiative to establish it came from Karl Christian Ulmann, a former professor at the University of Tartu, who was superintendent of the upper consistory. There was a great need for this because, as of 1847 , the Emperor no longer financed non-Orthodox ecclesiastical expenses. ${ }^{108}$ The relief fund received most of its funds from voluntary donations, fundraising and bequests. The money collected for the relief fund was used to build churches, pastorate buildings, houses of worship and associated schools. It was also used to pay pastors' salaries and travel expenses, maintain the schools and pay the parish clerk/schoolteachers. Former pastors were paid pensions and scholarships established for future pastors to study. ${ }^{109}$ The central committee of the relief fund was located in Saint Petersburg with committees

Io6 Neutatz, D. Zwischen Spracherhalt und Assimilierung. Russlanddeutsche und Donauschwaben vor 1914 im Vergleich. - Deutsche in Russland. Hrsg. von H. Rothe. (Studien zum Deutschtum im Osten, 27.) Böhlau, Köln et al., 1996, 62-63.

IO7 Kodu. Kool. Kirik. - Olevik, I892, 23, 477.

Io8 In the I840s the tsarist authorities attacked several Lutheran institutions, among others the authorities wanted to liquidate the Faculty of Theology of the University of Tartu. On the dismissal of Professor of the Faculty Karl Christian Ulmann see Tammiksaar, E. Ulmanni afärr Tartu Ülikoolis I842. a. novembris. - Akadeemia, I999, I2, 2576-2595.

I09 Amburger, E. Geschichte des Protestantismus in Rußland, 81, 82. 
in various parts of the country. ${ }^{110}$ In addition to the ten church parishes in the Caucasus under the Moscow Consistory, the Tbilisi Regional Committee also administered the synod district of the German colonies in the South Caucasus. ${ }^{111}$ Thus, although the colonial congregations, with their ecclesiastical organisation and liturgy, were not subordinated to the unified leadership of the Russian Evangelical Lutheran Church, the Church supported them through the relief fund.

If we examine the extent to which the Lutheran Church's relief fund supported the religious and education life of Estonians in Abkhazia, we can see that it was quite extensive. The first schoolhouse/prayer house was completed in the village of Estonia, where the classroom was also a prayer hall, and in 1887 , the aid fund donated 200 roubles to the construction of the school house. It is noteworthy that an additional 200 roubles were received from the adjacent Dranda Orthodox Monastery either as a loan ${ }^{112}$ or a donation ${ }^{113}$, the sources disagree about this. During the tenure of Pastor Bernhoff, with the support of the Tbilisi District Committee, three new prayer house/schoolhouses were built in the settlements around Sukhum: for the Germans in Gnadenberg and the Estonians in Alam-Linda, and a new one to replace the old one in Estonia, ${ }^{114}$ while the total amount necessary (I,688 roubles and I8 kopecks) was donated for the construction of the Alam-Linda schoolhouse. ${ }^{115}$ Although these were essentially school buildings, the buildings appear in official documents as "prayer house/schoolhouses" in both the Russian-language (молитвенно-икольное здание) and Germanlanguage documents (Bet-und Schulhaus). The reason was simple - it was only possible to receive financing for the construction of buildings from the Lutheran Church's relief fund if the building also performed the functions of a church or house of worship.

One could easily get the impression that the settlers used the needs of the church as cover to benefit the settlement schools. In fact, there are many reports of how contributions were made for the advancement of church life. After all, the relief fund only partially covered the needs of the

IIO Schleuning, J. Die Stummen reden, 99.

III Die evangelisch-lutherische Kirche Russlands im Werk ihrer Unterstützungs-Kasse im Jahre 1906. St. Petersburg, 1907, 74.

II2 Meomuttel, J. Eesti asunikud laialises Vene riigis, 45.

II3 Die Evangelisch-Lutherische Kirche Russlands im Werk ihrer Unterstützungs-Kasse im Jahre I89o. St. Petersburg, I891, 24.

II4 Sommer, S. Alam-Linda asunduse ajaloost EKLA 235.26.2, I6; Holberg, H. Estonia kiriku ja hariduse ajalugu. 9.0I.1919. EKLA 235.27.II.I, 3.

II5 Отчет о постройке молитвенно-школьного здания в сел. Нижне-Линда. 1907-1908. National Archives of Georgia. Central Historical Archive, Tbilisi (NAG, CHA), I620.I.II, $2-4$. 
pastors and parish clerk/schoolteachers. For example, the settlers in the villages of Estonia and Alam-Linda and Ülem-Linda organised concerts in order to raise money for a church bell. The longing for a church bell is expressed genuinely and sincerely by one settler as follows: "Those who are accustomed to the ringing of the church bell in their homeland may not even realise the longing that those of us who are abroad feel for it. Like the children of Israel in Babylon on Zion, we think sadly about our homeland, especially on Sundays, and listen in spirit as the bells in the church towers proclaim: 'This is the day of the Lord!' We listen but we don't hear anything." ${ }^{116}$ While in Estonia we are used to the fact that bells hung in church bell towers, in the settlements there was a separate bell tower or rather bell post in the yard. ${ }^{117}$ In Linda parties were organised to purchase an organ for the prayer house. ${ }^{118}$

In addition to satisfying the ecclesiastical needs of their villages, care was also taken, for instance, to build a church in the city of Sukhum. The church was completed in 1913. However, in late nineteenth century the inhabitants of the village of Estonia raised money for the construction of the church by organising theatre evenings and concerts. Even the few Orthodox Estonians in the village contributed to their Lutheran prayer house. ${ }^{119}$

The settlements received support from the relief fund to pay the parish clerk/schoolteachers their salaries - both as wage supplements and, for example, in poor crop years, one's entire yearly salary would be requested. ${ }^{120}$ The relief fund's annual reports show that the Estonians in Abkhazia very actively asked the relief fund for support, on their own and through their pastor. For example, the village of Estonia, which in the mid-I89os was the only one of the five Lutheran colonies in the Sukhum district to have hired a certified parish clerk/schoolteacher, consistently asked for school support. However, this was eventually reduced on the grounds that the village itself was prosperous enough. ${ }^{121}$ The relief fund usually paid the parish clerk/schoolteachers of the villages near Sukhum I5o roubles a year, ${ }^{122}$ which comprised a significant portion

\footnotetext{
II6 Suhum-Kalees. - Eesti Postimees, I898, 4I, 2; see also Chr. N. Kirjad Suhhumist. - Linda, 1899, 4 (22 January 1899), $58-59$.

II7 Опись имущества евангелическо-лютеранского филиального прихода "Естонского” в Сухумском округе, прихода Батум. Кутаис. І9І3. NAG, KCA II4.I.6, I.

II8 Chr. N. Suhum-Kaleest. - Postimees, I898, 4I, 3.

II9 Pihlakas, J. Kiri Suhum-Kaleest. - Eesti Postimees, I893, 4I, I, 2.

I20 Обер-пастор Закавказских евангелическо-лютеранских приходов. NAG, CHA I620.I.25, I-2, II.

I2I Die Evangelisch-Lutherische Kirche Russlands im Werk ihrer Unterstützungs-Kasse im Jahre I894. St. Petersburg, I895, 44.

I22 Die evangelisch-lutherische Kirche Russlands im Werk ihrer Unterstützungs-Kasse im Jahre 1904. St. Petersburg, 1905, 99.
} 
of their salary. In Estonia village, parish clerk/schoolteachers were paid 400 roubles a year, in Alam-Linda 390 roubles. In addition, the parish clerk/schoolteacher was given the use of two to three desyatina of land by the community. ${ }^{123}$ If in previous years the villages themselves along with the relief fund had to support the school teachers, because the state only paid a small extra bonus, then starting on I January 1912, the situation changed and the salaries of school teachers began to come entirely from the state. Now the community or relief fund only paid the parish clerk's salary. ${ }^{124}$

In 1903, a harmonium was ordered from Tartu for the newly completed school and prayer house in Sulevi and both the construction of the building and the purchase of the harmonium were supported in part by the relief fund of the Lutheran Church. ${ }^{125}$ Alam-Linda also received money from the relief fund for the purchase of a harmonium. ${ }^{126}$ And, as often occurs in financial matters, there were also quarrels when someone felt the benefits received from the fund had been misused. This is vividly reflected in the correspondence of the Tbilisi District Committee. ${ }^{127}$ At the same time, we can see from the materials of the relief fund what an important role communication with the homeland played in religious life - the Tbilisi District Committee provided financial support, but equipment was often ordered from Estonia.

\section{LUTHERAN CHURCH LIFE DURING WORLD WAR I AND THE RUSSIAN CIVIL WAR}

The outbreak of World War I led to the persecution of local Germans in tsarist Russia, which also affected Lutheran church life. Many (Baltic) German pastors were expelled for alleged German sympathies, leaving the congregations without pastors. German-language services were banned in the Black Sea region. Persecution also affected pastors in the Caucasus. For example, in 1914, the aforementioned pastor Adrian Schultz, who was highly praised by Estonians, was sent to Siberia. The church

I23 Die Evangelisch-Lutherischen Gemeinden in Russland, Bd. I, 85 .

I24 Sommer, S. Alam-Linda asunduse ajaloost EKLA 235.26.2, IO; Suhumi eestlastest. Postimees, 1912, 2, 2-3; Suhumist, Estonia asundusest. - Postimees, 1913, 28, 6.

I25 Ludvik, V. Sulevi küla ajalugu. EAM 284.I.39, I5; Die evangelisch-lutherische Kirche Russlands im Werk ihrer Unterstützungs-Kasse im Jahre 1903. St. Petersburg, 1904, 66.

I26 Die evangelisch-lutherische Kirche Russlands im Werk ihrer Unterstützungs-Kasse im Jahre I9OI. St. Petersburg, 1902, 63.

127 Отчет о постройке молитвенно-школьного здания в сел. Нижне-Линда. 1907-1908. NAG, CHA I620.I.II, I-3. 
authorities responded to the repressions by sending itinerant pastors to areas deprived of their pastors. ${ }^{128}$ When Estonian itinerate pastor and pastor of the Estonian congregation in Helsinki August Nigol arrived in the Estonian settlements in Abkhazia and the Caucasus in I9I5, many of the local young people had not been confirmed and some had married in the Orthodox Church without being confirmed, because there had been a long break in pastors' visits. ${ }^{129}$ Thus, Nigol had a lot of work to do, which is also reflected in his handwritten lists of baptisms, communion and confirmations. ${ }^{130}$

"This man's sermons were much more broad-minded", ${ }^{131}$ is how August Nigol is remembered in the villagers' memoirs. What they specifically meant by this is unclear. However, we do know that Nigol had been a primary and secondary school teacher before being ordained a church pastor, travelled through the Estonian settlements in Russia during his summer holidays, and organised the construction of Estonian school and society houses there. In his speeches, he called upon the inhabitants of the settlements to participate in nationalist social life. ${ }^{132}$

Nigol was already familiar with the Estonian settlements in Abkhazia. In I9IO, while working as a secondary school teacher in Rostov, he visited both Linda and Estonia and gave lectures on education. ${ }^{133}$ Later, Nigol encouraged the settlers in the Caucasus to consider establishing their own Estonian congregation instead of belonging to various German congregations. Nigol's vision was that the settlements' pastor would reside in Sukhum, but preach across a very wide area that would include the following: Alam-Linda, Ülem-Linda, Dubovka, Estonia, Punaselageda, Salme, Sulevi, Adler, Tuapse, Allmäe, Esto-Haginsk, Livonia, Maruha, Hussó-Kardonik, Armavir in the North Caucasus; as well as Tbilisi, Uus-Estonia, Baku and Pyatigorsk. ${ }^{134}$ The idea of having their own Estonian congregation gathered strong support among the settlers. In I916, articles introducing the congregation that was to be established were published in several Estonian newspapers and were signed by a number of activists from Estonian villages in Abkhazia. A name for the congregation was also proposed - the Estonian Congregation of

I28 Roemmich, H. Die evangelisch-lutherische Kirche in Rußland, 28; Amburger, E. Geschichte des Protestantismus in Rußland, 85; Amburger, E. Die Pastoren der evangelischen Kirchen Rußlands, 26, 467; Schleuning, J. Die Stummen reden, Ioo.

I29 Holberg, H. Estonia kiriku ja hariduse ajalugu. 9.0I.1919. EKLA 235.27.II, 2.

I30 Materials of pastor Nigol. NAG, CHA 1726.I.294, 295, 306.

I3I Ludvik, V. Sulevi küla ajalugu. EAM 284.I.39, I5.

I32 Välis-Eesti tegelased. Eluloolisi andmeid. Toim. B. Tiido. Välis-Eesti Ühing, Tallinn, 1939, 7I.

I33 Kaukasiast. - Sakala, I9IO, 43, 2.

I34 Nigol, A. Kahe uue Eesti koguduse asutamisest Oparinosse (Vologda kub.) ja Suhumi (Kaukasiasse). - Postimees, 1916, I82, 2. 
St. Paul in the Caucasus. The name Paul was justified by the fact that Paul the Apostle also travelled a great deal, which the pastor of the Estonian congregation in the Caucasus would also have to do. ${ }^{135}$ By the way, the Estonian congregation in Helsinki (organised by August Nigol) was also named after St. Paul. Nigol now published a draft statute for the proposed Estonian congregation in the Caucasus' several Estonian newspapers. ${ }^{136}$

When in May 1917 a congress of Estonian settlements in southern Russia, Crimea, the North Caucasus, the Black Sea coast, and the South Caucasus was convened in the Estonian settlement of Livonia in North Caucasus, the establishment of a joint Estonian congregation was discussed. The residence of the pastor in Sukhum was justified by the fact that a new Lutheran church building had just been completed there in 1913. ${ }^{137}$ At the congress, a disagreement arose between the settlers of the South and North Caucasus. The latter thought there should be two congregations instead of one, as the pastor would have to travel too far from Sukhum to the North Caucasus. However, the idea of one congregation won the most votes. ${ }^{138}$

During World War I, nothing came of the establishment of the Estonian congregation. In 1918, August Nigol, the main promoter of the congregation, was murdered by the Bolsheviks in Perm. ${ }^{139}$ As there were no pastors in Abkhazia, no services were held or sacraments performed. In 1920, when Sukhum was ruled by the Democratic Republic of Georgia, Estonians there complained that the young people were not confirmed and some had been married by Mingrelian priests without being confirmed. ${ }^{140}$ In January 1920, the Estonian congregation council was elected, and enquiries started to see if a pastor could be found in Estonia. ${ }^{141}$ However, when Soviet power arrived in Abkhazia in I92I, the issue became moot. In Soviet Russia, a decree was issued on 23 January I9I8 expropriating all church property and prohibiting religious education in all public and private schools. Now this order was expanded to

\footnotetext{
I35 Kaukasuse Eesti asunikkudele. - Tallinna Teataja, I916, I86, 2.

I36 Nigol, A. Kaukasia Eesti asunikkudele. - Postimees, I916, 214, 3; Nigol, A. Kaukasia eesti asunikkudele. - Pealinna Teataja, I916, 219, 2.

I37 Sommer, S. Alam-Linda asunduse ajaloost. EKLA 235.26.2, I7-I8.

I38 Saadik. Lóuna-Venemaa ja Kaukasia Eesti asunduste esimene kongress. - Päevaleht, I9I7, I39, 2.

I39 Välis-Eesti tegelased, 7I.

I40 Frisch, G. Kiri Kaukaasiast. - Postimees: Hommikuväljaanne, I920, 6I, 2.

I4I Mustamere ranna ja Taga-Kaukaasia jaoskonna Eesti asunduste keskkorraldus Evangeelikumi-Luteruse usu piiskopile Eesti Vabariigis. - Postimees, I920, II, 2.
} 
cover the recently conquered Caucasus. The older generation with their "religious prejudices" was to die out and give way to atheist youth. ${ }^{142}$

The emigration of Lutheran pastors from Bolshevik-ruled Russia began. A list has survived of those who took communion in the village of Estonia on 2I August 192I, i.e. a time when the Soviets had already been in power in Abkhazia for a few months. ${ }^{143}$ Thereafter, the parishioners took the Holy Communion and had their children baptised in the Lutheran church in Sukhum. The last public baptisms in the villages took place in 1928-1929. Subsequently baptisms were carried out in secret within family circles. Baptisms were usually carried out by older women. ${ }^{144}$ In 1937, the last nine Lutheran pastors still active in the Soviet Union were arrested. ${ }^{145}$ The aforementioned Pastor Wilhelm Heine, who had honed his Estonian in the village of Estonia and served the settlements there in I892-I893, was one of the few Lutheran clergy who did not leave Russia when the Bolsheviks came to power and was later able to serve several different congregations. In 1930, he was arrested and exiled to Siberia and settled near the river Ob. In 1934 he was allowed to leave, after which he settled in Feodosia, Crimea. In 1937 he was re-imprisoned and soon died in prison. ${ }^{146}$ The Lutheran congregation in Sukhum was active until 1934, when Pastor Martin Schraplau left for Germany. Religious services were later performed in secret by the members of the congregation themselves. ${ }^{147}$

The Lutheran Church in Abkhazia resumed its activities in 2003. The Church of St. John of Sukhum, which had been turned into an archive in the intervening years, was also reopened. The congregation has 30 to 40 members, mainly Germans. ${ }^{148}$ Estonians, of whom only a few dozen remain in Sukhum, no longer belong to the Church of St. John and do not attend services. The Estonian villages of Alam-Linda and Ülem-Linda near Sukhum have disappeared. Most of the inhabitants have moved to Estonia and some have resettled in Sukhum and the surrounding settlements. There are more, about a hundred, Estonians in the villages of Salme and Sulevi in northern Abkhazia. In 1990, Salme and Sulevi were visited by Villu Jürjo, an Estonian pastor, for the first time in many decades. In the second half of October 2orI, Pastor Arho Tuhkru,

I42 Roemmich, H. Die evangelisch-lutherische Kirche in Rußland, 34-35.

I43 List of villagers of Estonia. NAG, CHA I726.I.326.

I44 Mikkor, M. Kaukaasia eestlaste usuelust ja ristimistavadest. - Akadeemia, 200I, I3, 7, I492; 8,1770 .

I45 Amburger, E. Die Pastoren der evangelischen Kirchen Rußlands, 30, 370.

I46 Amburger, E. Die Pastoren der evangelischen Kirchen Rußlands, 342.

I47 Протокол допроса Христова Фридриха Фридриховича. 24.0I.I938. Archive of the Abchasian Institute of Humanities (AbIGI) 37.I.6, 5.

I48 Эшба, Э. Д. Современная религиозная ситуация в Абхазии, І2. 
who has served several congregations of the Estonian diaspora in both the West and in Russia, paid a visit to Estonian settlements in Abkhazia on behalf of the Mission Centre of Estonian Evangelical Lutheran Church. In the village of Sulevi, he conducted a religious funeral service, and was told that the last religious burial was conducted there in the early I930s. In the city of Ochamchira, he consecrated the house of an Estonian and blessed a couple who had married in 2009. ${ }^{149}$ Since then Lutheran clergy from Estonia have not visited Abkhazia.

\section{CONCLUSION}

The religious life of Estonians in Abkhazia discussed in this article was an isolated phenomenon from the point of view of the resident country. The Lutheran Church has had no contact with the indigenous Abkhazians. In the late nineteenth century, when the villages of the Estonians, Germans and others were established, the Abkhazians were banned from living in the areas designated for colonisation. Moreover, the Abkhazians were predominantly Muslim and Orthodox. A Lutheran mission similar to the one to the Muslims in the eastern Caucasus did not take place in Abkhazia. Both Lutheranism and, for example, Catholicism remained foreign to the Abkhazians, as a typical manifestation of colonialism and postcolonialism. Although isolated from local religious life, Lutheranism has existed in Abkhazia and been in contact with the homeland and the national Lutheran church network. The Lutheran Church played an important role in maintaining the transnational ties of the Estonian diaspora with the Estonian homeland.

The Lutheran parish included both German and Estonian villages in Abkhazia. The settlements were served by (Baltic) German pastors who had been educated at the Faculty of Theology at the University of Tartu, with most also being born in Estonia so they were able to serve Estonian settlers in Estonian. The pastors visited the settlements once or twice a year. The Lutheran Church of St. John, founded in Sukhum in 1913, was attended mainly by Germans, but also by Estonians. Estonians also served on the local church council.

Since the pastors seldom visited the settlements, a key role in teaching religion and conducting the services was played by the parish clerk/schoolteachers, a position that was important to the religious and 
education lives in Estonian settlements throughout tsarist Russia. Considering the role of the Lutheran Church in educating the Estonians into a literary nation, we have to view the Church as effective beyond the walls of church buildings. The school was a child of the church, especially in the settlements where the construction of schoolhouses and salaries of the schoolteachers was largely supported by the Lutheran Church relief fund. Therefore, Lutheranism was something more than a religion also in a material sense. In a spiritual sense the education provided in the schools supported by the church made it possible to participate in the Estonian media field, which helped strengthen the Estonian national identity in the diaspora, and in some areas even shaped it. In the eyes of the church, the main job of the parish clerk/schoolteachers may have been to stand in for the pastors while they were away, but the parish clerk/schoolteachers educated people on a far broader scale than was required by the church for proselytising. The parish clerk/schoolteachers organised theatre groups, instrumental and vocal choirs and social life more generally. They were also the main activists in developing communication between the settlements with the Estonian homeland, wrote articles about life in the settlements in the Estonian press and helped Estonian literature and music reach the settlements.

Since the church, the school and cultural life in general were closely related in the Estonian settlements, the impact of the Soviet-era repressions against the church on these settlements extended beyond the religious sphere. In addition to the fact that most of the pastors and parish clerk/schoolteachers left for Estonia, the public practice of religion was gradually banned. After the establishment of Soviet power, the ties that had connected the Estonian settlements with the homeland and ensured its cultural influence on the settlements were cut for many decades. As Estonian settlers perceived Lutheranism to be the 'Estonian religion', the anti-religious repressions also affected Estonian identity. The ties with the homeland maintained through the church were severed. In recent decades, there have been a few visits by Estonian pastors to the Estonians in Abkhazia, but regular ties, which would approximate those of the tsarist era, have not been restored.

\section{Acknowledgments}

The preparation of this article has been supported by the Estonian Research Council's research project IUT316, A Transnational Setting for Estonian History: Transcultural Entanglements, International Organisations and Transborder Migrations (I6th-2Ist Centuries). 


\title{
ABHAASIA EESTI ASUNDUSTE USUELU JA SELLE SEOSED EESTIGA
}

\author{
Aivar Jürgenson
}

Artiklis käsitletud eestlaste usuelu Abhaasias oli sihtmaa seisukohast isoleeritud nähtus. Luteri kirikul ei ole olnud kontakte pôliselanike abhaasidega. Abhaasidel oli i9. sajandi lópukümnendeil, kui rajati eestlaste, sakslaste jt külad, kolonisatsiooniks määratud piirkondades elamine keelatud, pealegi olid abhaasid valdavalt moslemid ja óigeusklikud. Sarnast luterlikku misjonit, mis leidis aset Kaukaasia idaosa moslemite juurde, Abhaasias ei toimunud. Nii luterlus kui ka näiteks katoliiklus jäid abhaasidele võóraks, olles tüüpilised kolonialismi ja postkolonialismi ilmingud. Kuigi kohalikust usuelust isoleeritud, on luterlus eksisteerinud Abhaasias aga kontaktis emamaa ja üleriikliku luteriusu kirikliku vôrgustikuga. Eesti diasporaa rahvusüleste sidemete säilitamises emamaa Eestiga oli luteri kirikul oluline roll.

Luteri kirikukihelkond hôlmas Abhaasias nii saksa kui eesti külasid, asundusi teenisid (balti)saksa pastorid, kes olid saanud hariduse Tartu Ülikooli usuteaduskonnas ja valdavalt ka sündinud Eestis, mistôttu suutsid teenida eesti asunikke eesti keeles. Pastorid külastasid asundusi kord või paar aastas. Suhhumis I9I3. aastal valminud luteriusu Johannese kirikus käisid peamiselt sakslased, kuid ka eestlased. Eestlasi oli ka kohalikus kirikunôukogus.

Kuna kirikuópetaja külastas asundusi harva, lasus peamine roll usuópetuse andmisel ja sakramentide jagamisel köster-koolmeistritel institutsioon, mille tähtsus religioosses ja hariduselus oli eesti asundustes üle tsaaririigi väga oluline. Arvestades luteri kiriku traditsiooni eestlaste harimisel kirjarahvaks, tuleb kiriku rollis näha midagi, mis ulatub väljapoole kirikuseinu. Kool oli kiriku laps, seda eriti asundustes, kus koolimajade ehitamist ja koolmeistrite ülalpidamist toetas suurel määral luteri kiriku abikassa. Luterlus oli seega midagi enamat kui religioon, seda ka materiaalses plaanis. Kuid ka vaimses plaanis - kiriku poolt toetatavates koolides jagatav haridus tegi võimalikuks osasaamise eesti meediaruumist, mis diasporaas aitas tugevdada rahvuslikku identiteeti ja mônes piirkonnas koguni oli selle kujundajaks. Köster-koolmeistrite pôhitöö vôis kiriku silmis küll olla pastori asendamine ajal, mil see eemal viibis, kuid köster-koolmeister teostas rahva harimist kaugelt laiemal rindel kui kirikul ususôna levitamiseks hädatarvilik. Köster-koolmeistrid juhatasid näitemänguringe, pilli- ja laulukoore ning organiseerisid seltsielu 
laiemalt. Samuti olid nad peamised aktivistid, kes arendasid asunduste sidemeid emamaa Eestiga, valgustades emamaa lugejat Eesti ajakirjanduses asunduste elust kirjutatud ülevaadetega ja vahendades asundustesse eesti kirjandust ja heliloomingut.

Kuna kirik, kool ja laiemalt kultuurielu olid eesti asundustes tihedalt seotud, tabasid nôukogudeaegsed kirikuvastased repressioonid eesti asundusi hoopis laiemalt kui vaid religioosses sfääris. Lisaks sellele, et kirikuôpetajad ja köster-koolmeistrid lahkusid suures osas Eestisse, keelati järkjärgult ka usu avalik praktiseerimine. Nõukogude vôimu kehtestamise järel lóigati läbi sidemed, mis olid pikkade aastakümnete jooksul sidunud eesti asundusi emamaaga ning taganud selle kultuurilise môju asundustele. Kuna eesti asunikud tajusid luterlust eesti usuna, môjutasid usuvastased repressioonid ka eesti identiteeti laiemalt. Kiriku liinis hoitud sidemed emamaaga katkesid. Viimastel kümnenditel on toimunud küll üksikuid eesti pastorite visiite Abhaasia eestlaste juurde, kuid regulaarsed sidemed, mis oleksid ligilähedaseltki vôrreldavad tsaariaegsetega, pole taastunud. 